\title{
Nutritional Analysis of Fast Food in Streets of Patna
}

\section{Town, Bihar}

\author{
Abha Rani $^{1}$ and Anju Srivastava ${ }^{2}$ \\ 1. Dept. of Home Science, Magadh Mahila College, Patna University, Patna 800001, Bihar, India \\ 2. PG Dept. of Home Science, Magadh Mahila College, Patna University, Patna 800001, Bihar, India
}

\begin{abstract}
Mushroom growth of street fast food is a boon for changing lifestyle of urban people. However, its nutritional aspect is also a matter of concern. The objective of the present study was hence to assess the nutrient components of fast food sold in streets of Patna town. A total of 30 fast food samples from streets were collected from different locations of Patna town in aseptic containers and immediately transferred to the laboratory for proximate analysis. Descriptive statistics was used to analyze the collected data. In terms of nutrient contribution, the highest energy content was found in Hot potato chips (536 $\pm 85.2 \mathrm{kcal} / 100$ g) followed by Chicken chawmin (527 $\pm 253.08 \mathrm{kcal} /$ plat), Chilli chicken (464 $\pm 91.8 \mathrm{kcal} / \mathrm{plat})$ and Pav bhaji (425 $\pm 164 \mathrm{kcal} / \mathrm{plat})$. Highest level of protein was detected in Chilli chicken at $27.3 \pm 5.01 \mathrm{~g}$ per serving. Protein of Chilli chicken supplied approximately $29 \%$ of the total energy content per serving. Maximum amount of fat was also found in Chilli ckicken (35.5 $\pm 31.89 \mathrm{~g} / \mathrm{plat}$ ). Total fat contribution of Chilli ckicken to the total energy per serving found to be approximately $67 \%$. Highest level of carbohydrate was detected in Idli at $15.0 \pm 9.18$ g per serving of sample which contributed approximately $91 \%$ of the total energy content per serving. From this study it was concluded that street fast foods provide an appreciable amount of recommended nutrient composition. It could be observed in this study that street fast foods supply appreciable amount of nutrients and calories to the people of Patna.
\end{abstract}

Key words: Street fast food, proximate analysis, nutritional composition.

\section{Introduction}

Street fast foods are ready-to-eat foods that can be bought directly from street vendors or hawkers or at local markets and eaten immediately i.e. without necessarily having to cook before consumption as they have been already prepared by the vendors. These are very popular worldwide and provide readily available delicacies at a cheaper rate. Street vended food, even when produced under low level of hygiene, is usually consumed regardless of the source of production or quality of raw materials use [1]. Changing life style and busy schedule of the people, resulted in uncontrolled growth and mushrooming of street food vendors, food joints, fast food corners, public food establishments etc. Familiarity, low cost, tastes and consumer conveniences are some of the other appealing factors that make street fast foods popular

Corresponding author: Abha Rani, research scholar (JRF), research fields: food and nutrition.
[2]. The street food industry plays an important role in meeting the food requirements of urban dwellers in many cities and towns of developing countries. The industry feeds millions of people daily with a wide variety of foods that are relatively cheap and easily accessible by the people.

In the majority of studies was demonstrated that street fast food provides variable quantities of nutrients and energy to the diet of children and adults in developing countries [3]. The nutritional value of street fast foods depends on the ingredients used and how they are prepared, stored and sold, as occurs with other foods. It is essential to have a good understanding of the type and nutritional value of street fast foods since their consumption in many countries has become entrenched in habitual eating patterns and may influence the development of chronic noncommunicable diseases and other nutrition-related conditions in the population [3-5]. 
Street fast food ingredients are country/region specific and rarely they are reported and/or analyzed $[6,7]$. Patna being the capital of Bihar is a very popular city and also one of the most populated cities of India. Patna is a major institutional hub and also a tourist spot. Migration of youth and other people from rural areas and other parts of the country to Patna for better education and commercial business and for visiting heritage place of Patna, creates a heavy demand for inexpensive ready-to-eat food. To ensure the nutritional quality of the diet of people who consume street fast foods it is essential that the nutritional composition of street fast food be analyzed and reported. The objective of the present study was hence to analyzed the nutritional composition of fast food sold by small vendors in the streets of Patna town.

\section{Materials and Methods}

\subsection{Collection of Samples}

A total of 30 street vending fast food samples were collected from different locations of Patna town in an aseptic container and immediately transferred to the laboratory for proximate analysis.

\subsection{Determination of Proximate Composition}

The proximate composition of the street fast food made in practise was analysed by approved AOAC (Association of Analytical Chemists) methods [8]. The moisture, ash, crude fat, crude fibre, and crude protein and carbohydrate contents of each food sample were analyzed. Moisture content was determined by heating $2.0 \mathrm{~g}$ of each fresh sample to a constant weight in a crucible placed in an oven maintained at $105{ }^{\circ} \mathrm{C}$. The ash content was determined by the incineration of $5 \mathrm{~g}$ samples placed in a muffle furnace maintained at $550{ }^{\circ} \mathrm{C}$ for $5-8 \mathrm{hrs}$. The crude fibre was obtained by digesting $5 \mathrm{~g}$ of the samples with $\mathrm{H}_{2} \mathrm{SO} 4$ and $\mathrm{NaOH}$ and incinerating the residue in a muffle furnace maintained at $550{ }^{\circ} \mathrm{C}$ for $5-8$ hrs. The crude protein (\% total nitrogen $\mathrm{X}$ 6.25) was determined by
Kjeldahl method, using $2 \mathrm{~g}$ of the samples. The crude lipid content was obtained by extracting $5 \mathrm{~g}$ of each sample in a Soxhlet apparatus using Petroleum ether boiling point $60-80^{\circ} \mathrm{C}$ as the extractant. Each analysis was carried out in triplicates. The carbohydrate content was determined by the difference i.e. deducing the sum of the percentage (moisture, ash, fibre, fat, and protein) from 100.

\subsection{Statistical Analysis}

Data were analyzed using the Statistical Package for Social Sciences (SPSS) program version 11. Descriptive statistics such as percentage means and standard deviation were used to present the findings.

\section{Results and Discussion}

The results of proximate analysis of 30 street fast food samples are provided in Table 1.

\subsection{Assessment of Nutritional Composition}

\subsubsection{Moisture}

It could be observed in this study that the moisture content of street fast foods varied greatly depending upon the types of food, their cooking methods and consumers' choice.

\subsubsection{Ash}

Ash is the residue of mineral. Results of study indicated that among sampled foods Pav bhaji, Burger, Chhole bhature, Gulab jamun, Chilli chicken and Chana bhaji had considerable amount of ash. Their ash content per serving was $6.7 \pm 4 \mathrm{~g}, 5.0 \pm 3 \mathrm{~g}, 4.5 \pm$ $3 \mathrm{~g}, 4.0 \pm 1 \mathrm{~g}, 2.5 \pm 2 \mathrm{~g}$ and $2.3 \pm 0.3 \mathrm{~g}$ respectively.

\subsubsection{Energy}

The National Institute of Nutrition (NIN) 2010 dietary guidelines recommend that the RDA for energy is about 2,320 kcal per day for a sedentary man and 2,100 kcal per day for a sedentary women and 1,900 kcal for children age groups 10-12 yrs. The data obtained showed that energy content in the 30 street fast food samples in kcal per serving of sample was in 
Table 1 Proximate composition of the street fast foods.

\begin{tabular}{|c|c|c|c|c|c|c|c|c|c|}
\hline $\begin{array}{l}\text { Sl. } \\
\text { No. }\end{array}$ & $\begin{array}{l}\text { Name of street } \\
\text { fast food }\end{array}$ & $\begin{array}{l}\text { Serving } \\
\text { size }\end{array}$ & $\begin{array}{l}\text { Moisture (\%) } \\
(\text { mean } \pm \text { SD) }\end{array}$ & $\begin{array}{l}\text { Ash }(g) \\
(\text { mean } \pm \text { SD) }\end{array}$ & $\begin{array}{l}\text { Protein (g) } \\
(\text { mean } \pm \text { SD) }\end{array}$ & $\begin{array}{l}\text { Fat }(g) \\
(\text { mean } \pm S D)\end{array}$ & $\begin{array}{l}\text { Fibre (g) } \\
(\text { mean } \pm \text { SD) }\end{array}$ & $\begin{array}{l}\mathrm{CHO}(\mathrm{g}) \\
(\mathrm{mean} \pm \mathrm{SD})\end{array}$ & $\begin{array}{l}\text { Energy (Kcal) } \\
(\text { mean } \pm \text { SD) }\end{array}$ \\
\hline 1 & Idli & $1 \mathrm{pc}$ & $44 \pm 20.04$ & $0.9 \pm 0.8$ & $1.2 \pm 2$ & $0.2 \pm 0.4$ & $0.1 \pm 0.2$ & $15.0 \pm 9.18$ & $66.6 \pm 34.9$ \\
\hline 2 & Plain Dosa & $1 \mathrm{pc}$ & $59 \pm 12.12$ & $2.3 \pm 0.3$ & $2.8 \pm 2.1$ & $5.2 \pm 0.5$ & $0.8 \pm 0.9$ & $21.5 \pm 8.09$ & $144 \pm 47.23$ \\
\hline 3 & Sambher & 1 bowl & $80 \pm 10.6$ & $0.6 \pm 2$ & $5.6 \pm 1.9$ & $2.5 \pm 3.12$ & $0.3 \pm 1.0$ & $18.4 \pm 14.98$ & $119 \pm 81.9$ \\
\hline 4 & $\begin{array}{l}\text { Chhole } \\
\text { bhature }\end{array}$ & 1 plate & $60 \pm 20.12$ & $4.5 \pm 3$ & $10.7 \pm 2.18$ & $12.6 \pm 16.0$ & $4 \pm 3.09$ & $41.4 \pm 23.12$ & $321.8 \pm 74.6$ \\
\hline 5 & Bread pokora & $1 \mathrm{pc}$ & $61 \pm 5.6$ & $0.7 \pm 0.1$ & $2.2 \pm 4.01$ & $9.4 \pm 10.2$ & $0.9 \pm 0.5$ & $12.0 \pm 6.67$ & $141.8 \pm 42.90$ \\
\hline 6 & Onion pokora & 3 pcs & $52 \pm 9.02$ & $0.9 \pm 0.5$ & $3.7 \pm 2.1$ & $11 \pm 11.22$ & $0.3 \pm 0.2$ & $14.9 \pm 8.09$ & $171.5 \pm 48.64$ \\
\hline 7 & Gulab jamun & 2 pcs & $52.8 \pm 13.68$ & $4.0 \pm 1$ & $6.7 \pm 4.12$ & $12.9 \pm 5.78$ & $0.55 \pm 2.01$ & $46.6 \pm 32.4$ & $329.3 \pm 142.12$ \\
\hline 8 & Jalebi & $2 \mathrm{pcs}$ & $30 \pm 18.18$ & $1.2 \pm 0.9$ & $5.0 \pm 2.22$ & $14.1 \pm 6.9$ & $0.01 \pm 1.09$ & $28.0 \pm 21.9$ & $259 \pm 121.89$ \\
\hline 9 & Litti & $1 \mathrm{pc}$ & $38.3 \pm 12.0$ & $1.2 \pm 0.1$ & $5.0 \pm 2.6$ & $0.5 \pm 0.9$ & $0.15 \pm 0.05$ & $24.0 \pm 8.09$ & $120.5 \pm 52.10$ \\
\hline 10 & $\begin{array}{l}\text { Bagan ka } \\
\text { bharta }\end{array}$ & $100 \mathrm{~g}$ & $85.4 \pm 8.9$ & $0.9 \pm 0.8$ & $1.2 \pm 0.6$ & $5.7 \pm 4.12$ & $2.5 \pm 2$ & $5.70 \pm 5.9$ & $72.6 \pm 34.61$ \\
\hline 11 & Pav bhaji & 1 plate & $44 \pm 21.0$ & $6.7 \pm 4$ & $16 \pm 4.4$ & $21 \pm 16.0$ & $3 \pm 2.09$ & $43.0 \pm 34.12$ & 164.0 \\
\hline 12 & Burger & $1 \mathrm{pc}$ & $26.0 \pm 29$ & $5.0 \pm 3$ & $8.8 \pm 3.1$ & $10.5 \pm 12.98$ & $1.4 \pm 2.1$ & $36.0 \pm 27.12$ & $273 \pm 119.2$ \\
\hline 13 & Chilli chicken & 1 plate & $62.0 \pm 32.1$ & $2.5 \pm 2$ & $27.3 \pm 5.01$ & $35.5 \pm 31.89$ & $0.3 \pm 1.09$ & $8.80 \pm 8.98$ & $464 \pm 91.8$ \\
\hline 14 & Chawmein & 1 plate & $54.0 \pm 14.8$ & $1.2 \pm 1.5$ & $4.0 \pm 4.01$ & $24.2 \pm 22.8$ & - & $49.6 \pm 33.09$ & $432 \pm 161$ \\
\hline 15 & Pani puri & $1 \mathrm{pc}$ & $84.0 \pm 10.3$ & - & $0.5 \pm 0.6$ & $2.5 \pm 0.04$ & - & $8.00 \pm 2.2$ & $54 \pm 11.98$ \\
\hline 16 & Bhel puri & $25 \mathrm{~g}$ & $11.0 \pm 8.0$ & $0.1 \pm 0.5$ & $2.0 \pm 3.8$ & $0.5 \pm 0.1$ & - & $23.0 \pm 8.18$ & $104 \pm 55.8$ \\
\hline 17 & Samosa & $1 \mathrm{pc}$ & $54.0 \pm 10.4$ & $1.0 \pm 0.9$ & $4.0 \pm 5.7$ & $12.6 \pm 14.19$ & $1.7 \pm 2.0$ & $41.0 \pm 32.12$ & $293 \pm 199$ \\
\hline 18 & Tikki chat & 1 plate & $69 \pm 23.12$ & $1.1 \pm 0.9$ & $4.7 \pm 7.89$ & $9.1 \pm 9.9$ & $0.2 \pm 1.9$ & $38.0 \pm 36.9$ & $252 \pm 187.8$ \\
\hline 19 & Samosa chat & 1 plate & $64 \pm 26.2$ & $1.2 \pm 0.8$ & $7.4 \pm 6.19$ & $14.1 \pm 9.86$ & $1.2 \pm 1.67$ & $56.0 \pm 45.7$ & $380 \pm 201$ \\
\hline 20 & Egg roll & $1 \mathrm{pc}$ & $63 \pm 5.01$ & $1.6 \pm 0.5$ & $9.0 \pm 2.12$ & $11 \pm 0.6$ & $1.0 \pm 0.5$ & $18.0 \pm 9.98$ & $207 \pm 53.4$ \\
\hline 21 & Veg roll & $1 \mathrm{pc}$ & $44 \pm 10.6$ & $0.6 \pm 0.56$ & $0.6 \pm 3.12$ & $5.0 \pm 0.4$ & $0.3 \pm 0.5$ & $18.0 \pm 8.89$ & $127 \pm 57.1$ \\
\hline 22 & Jeera rice & 1 plate & $68.0 \pm 6.1$ & $0.4 \pm 0.1$ & $5.5 \pm 0.9$ & $4.4 \pm 4.32$ & - & $50.0 \pm 22.31$ & $222 \pm 91.2$ \\
\hline 23 & Chhole & 1 bowl & $65 \pm 32.12$ & $2.2 \pm 1.9$ & $7.7 \pm 8.9$ & $7.6 \pm 8.90$ & $0.22 \pm 1.12$ & $25.4 \pm 21.13$ & $202 \pm 127.6$ \\
\hline 24 & Dal vada & 2 pcs & $58 \pm 6.23$ & $1.2 \pm 0.9$ & $7.2 \pm 0.4$ & $7.9 \pm 4.08$ & $0.6 \pm 1.31$ & $17.8 \pm 10.9$ & $171 \pm 51.11$ \\
\hline 25 & $\begin{array}{l}\text { Chicken } \\
\text { chowmein }\end{array}$ & 1 plate & $52 \pm 8.65$ & $1.4 \pm 1.1$ & \pm 9.1 & $29 \pm 25.91$ & $0.3 \pm 2.12$ & $49.6 \pm 48.44$ & 53.08 \\
\hline 26 & Momo & 1 plate & $55 \pm 5.01$ & $0.5 \pm 0.12$ & $15.3 \pm 1.12$ & $1.3 \pm 0.09$ & - & $73.9 \pm 9.9$ & $376 \pm 46.7$ \\
\hline 27 & $\begin{array}{l}\text { Hot potato } \\
\text { chips }\end{array}$ & $100 \mathrm{~g}$ & 0.00 & 0.04 & $7.0 \pm 4.12$ & $34.8 \pm 37.91$ & $3.0 \pm 2.19$ & $52.8 \pm 12.1$ & $536 \pm 85.2$ \\
\hline 28 & Dahi vada & $2 \mathrm{pc}$ & $76 \pm 20.04$ & $1.6 \pm 0.8$ & $12.1 \pm 9$ & $11.2 \pm 4$ & $0.4 \pm 2$ & $35.0 \pm 18$ & $301 \pm 117$ \\
\hline 29 & Chana bhaji & 1 plate & $69 \pm 12.12$ & $2.3 \pm 0.3$ & $6.07 \pm 2.1$ & $0.7 \pm 0.3$ & $1.25 \pm 0.9$ & $21.5 \pm 8.09$ & $122 \pm 42.23$ \\
\hline 30 & $\begin{array}{l}\text { Roasted mixed } \\
\text { bhuja }\end{array}$ & 1 & $22 \pm 10.6$ & $1.6 \pm 2$ & $15.6 \pm 11$ & $6.5 \pm 3.12$ & $2.6 \pm 2.1$ & $57.4 \pm 44.98$ & $365 \pm 235.9$ \\
\hline
\end{tabular}

the range 54 to 536. The highest energy content was found in Hot potato chips (536 $\pm 85.2 \mathrm{kcal} / 100 \mathrm{~g})$ followed by Chicken chawmin (527 \pm 253.08 kcal/plat), Chilli chicken (464 $\pm 91.8 \mathrm{kcal} / \mathrm{plat})$ and Pav bhaji (425 \pm 164 kcal/plat).

Average energy content in Pani puri was $54 \pm 11.98$ kcal, in Idli $66.6 \pm 34.9 \mathrm{kcal}$ in Plain dosa was $144 \pm$ $47.23 \mathrm{kcal}$ in Veg roll $127 \pm 57.1 \mathrm{kcal}$, in Egg roll 207 $\pm 53.4 \mathrm{kcal}$ and in Litti was $120.5 \pm 52.10 \mathrm{kcal}$ per pc.

Average energy content in Bhel puri was $104 \pm 55.8$ kcal per 25 g. Average energy content in Bagan ka bharta was $72.6 \pm 34.61 \mathrm{kcal}$, in Sambher $119 \pm 81.9$ kcal and In Chana bhaji was $122 \pm 42.23$ kcal per serving.

\subsubsection{Protein}

The Indian dietary guidelines (NIN, 2011) recommends that $10 \%-15 \%$ calorie should be from protein. Among 30 sample highest level of protein was detected in Chilli chicken at $27.3 \pm 5.01$ g per serving. Protein of Chilli chicken supplied approximately $29 \%$ of the total energy content per serving. Egg Roll, Roasted mixed bhuja, Dal vada and 
Momo also had significant amount of protein. Per serving approximately $20 \%$ of energy was provided by protein of these fast food.

\subsubsection{Fats}

The Indian dietary guidelines (NIN, 2011) recommends that 20-30 percent of calories should be from total fat. Per serving maximum amount of fats was found in Chilli ckicken ( $35.5 \pm 31.89 \mathrm{~g}$ ). Total fat contribution of Chilli ckicken to the total energy per serving found to be approximately $67 \%$ followed by Hot potato chips (34.8 \pm 37.91 g, $58 \%$ of total energy), Chawmin $(24.2 \pm 22.8 \mathrm{~g}, 50 \%$ of total energy), Chicken chawmin ( $29 \pm 25.91 \mathrm{~g}, 49 \%$ of total energy) and Pav bhaji ( $21 \pm 16.0 \mathrm{~g}$, $44 \%$ of total energy). Level of fat was found to be very high in these street fast food.

Idli, Momo, Litti, Bhel Puri, Chana bhaji, were very low fat containing street fast food. These fast food would contributed fat $0.2 \pm 0.4 \mathrm{~g}$ ( $2.7 \%$ of total energy), $1.3 \pm 0.09 \mathrm{~g}$ (3.1\% of total energy), $0.5 \pm 0.9$ g (3.7\% of total energy), $0.5 \pm 0.1 \mathrm{~g}$ ( $4.3 \%$ of total energy), $0.7 \pm 0.3 \mathrm{~g}$ ( $5.1 \%$ of total energy) per serving respectively.

\subsubsection{Fibre}

Results of proximate analysis showed that street fast foods had little fibre or roughage. Sampled foods were generally made from processed food grain. Processing resulted in loss of fibre content as they are present in outer parts of food grains which are removed by processing. However some street fast food such as Chhole bhature, Pav bhaji, Bagan ka bharta, Roasted mixed bhuja,Burger, Samosa, Chana bhaji had appreciable amount of fibre as they made from either whole grains or vegetatables which are rich source of fibre.

\subsubsection{Carbohydrate}

NIN reccommends $50 \%-60 \%$ of the total energy intake from carbohydrates. Among selected food sample Idli, Jeera rice, Bhel puri, Litti, and Momo were rich in carbohydrate content.

Highest level of carbohydrate was detected in Idli at
$15.0 \pm 9.18 \mathrm{~g}$ per serving of sample which contributed approximately $91 \%$ of the total energy content per serving followed by Jeera rice ( $50.0 \pm 22.31 \mathrm{~g}, 90 \%$ of total energy), Bhel puri (23.0 $\pm 8.18 \mathrm{~g}, 88 \%$ of total energy), Litti ( $24.0 \pm 8.09$ g, $80 \%$ of total energy), Momo (73.9 \pm 9.9 g, $76 \%$ of total energy per serving of sample).

Chilli chicken, Bagan ka bharta, Bread pokora, Egg roll, Onion pokora, Chicken chowmein were food with a low carbohydrate. Their carbohydrate content was found to be $8.80 \pm 8.98 \mathrm{~g}, 5.70 \pm 5.9 \mathrm{~g}, 12.0 \pm$ $6.67 \mathrm{~g}, 18.0 \pm 9.98 \mathrm{~g}, 14.9 \pm 8.09 \mathrm{~g}$ and $49.6 \pm 48.44 \mathrm{~g}$ respectively which was approximately $8 \%, 33 \%, 34 \%$, $34 \%, 35 \%$, $38 \%$ of total energy per serving of sample respectively.

\section{Conclusions}

From this study it was concluded that, street fast foods provide an appreciable amount of recommended nutrient composition. Consumption of a substantial quantity of the street fast foods as well as right combination of the quality and quantity of foods would serve as a means of obtaining a good nutritionally balanced meal outside the home and subsequently meeting the required ration for body development.

\section{References}

[1] Sobukola, O. O., Awonorin S. O., Idowu M. A., and Bamiro F. O. 2008. "Chemical and Physical Hazard Profile of Robo Processing-A Street Vended Melon Snack.” Intl. J. Food. Sci. Technol. 43: 237-40.

[2] Hanashiro, A., Morita, M., Matte, G., R., Matte, M. H., and Torres, E. A., 2005. "Microbiological Quality of Selected Street Foods from a Restricted Area of Sao Paulo City, Brazil.” Food Control. 16: 439-44.

[3] Steyn, N. P., Mchiza, Z., Hill, J., Davids, Y. D., and Venter, I. 2013. "Nutritional Contribution of Street Foods to the Diet of People in Developing Countries: A Systematic Review.” Public Health Nutr. 17: 1363-74.

[4] Haslam, D. W., and James, W. P. T. 2005. "Obesity." Lancet 366: 1197-209.

[5] Lobstein, T., Baur, L., and Uauy, R. 2006. "Obesity in Children and Young People: A Crisis in Public Health.” Obes Rev. 5: 4-104. 
[6] Namugumya, B. S., Muyanja, C. 2011. "Contribution of Street Foods to the Dietary Needs of Street Food Vendors in Kampala, Jinja and Masaka Districts, Uganda.” Public Health Nutrition 15: 1503-11.

[7] Draper, A. 1996. Street Foods in Developing Countries:
The Potential for Micronutrient Fortification. John Snow, Inc/OMNI Project.

[8] AOAC. 1980. Official Methods of Analysis. 11th edition. Washington DC. Association of Analytical Chemists, USA. 